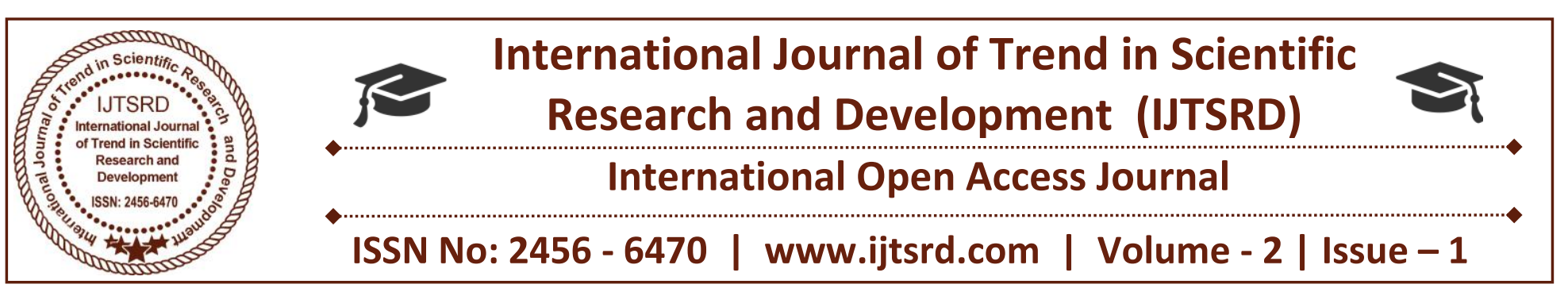

\title{
Employee Satisfaction and Quality of Work Life: A Review of Literature
}

\author{
Arnab Kumar Samanta \\ Lecturer \& Research Scholar, Dept. of Commerce \& BBA, \\ Netaji Mahavidyalaya, Arambagh, West Bengal
}

\section{ABSTRACT}

The success of any organization is highly dependent on how it attracts, recruits, motivates and retains its employee. Today's organizations need to be more flexible so that they are equipped to develop their employees and enjoy their commitment. Therefore, organizations are required to adopt a strategy to improve the employees quality of work life to satisfy both the organizational objectives and employee needs. It seeks to create culture of work commitment in the organization which will ensure higher productivity for the company and greater job satisfaction for the employees. The aim of my study is to learn and identify the factors affecting the quality of work life as well as employee satisfaction through the review of literatures which ultimately affect the results and performance of an organization. The most important determinants of Quality of Work Life (QWL) is the career growth opportunities, Safe and healthy working condition and of employee satisfaction are Compensation and Benefit, job satisfaction, promotion and development and working conditions as supported by various researches done in past.

Keywords: Employee, Satisfaction, Quality of Work life

\section{Introduction:}

Thinking of human resources as an asset in an organization has come in a long way, starting from the time office to personnel management to Human Resource Management since 1960s. However, from 1990 onwards the growth of knowledge based organizations like Information Technology industries and other service sector businesses made the managers to feel and realize the fact that the major differentiators and uniqueness of the organization comes from its human resources. Since then the approach of personnel or human resource management has become employee centric, considering human resources as an asset, keeping them at best of the humor and creating a pride in the mindsets. The behavior and treatment of a manager towards its staffs would affect their attitude and working behavior. Today the affectivity and high function of organizations will not occur without the assistance and cooperation of the employees. Thus emphasize was always on the various needs and satisfaction level of the employees which determines their efficiency and effectiveness. To begin with, quality of work life is such a concept that directly related to the satisfaction. quality of work life (QWL) means satisfaction of an employee to meet his/her needs from sources, activities and the results acquired from involvement in the working environment (Goudarzwand Chegini \& Mirdozande, 2010). The difference between the quality of work life and job satisfaction is at this point that job satisfaction is one of the results of the quality of working life (Mirkamali \& Narenji Sani, 2008). Walton (1975) mentioned, dissatisfaction with work life is a problem, which affects almost all workers at one time, or another, regardless of position or status. QWL stimulates the employee job satisfaction and is essential for improving organizational and operational productivity (Tabassum, Rahma, \& Jahan, 2011). In fact, Quality of work life indicates a proper balance both in work and personal life which also ensure organizational productivity and employee's job satisfaction. 


\section{Concept of Employee Satisfaction}

Employee satisfaction is a measure of how happy workers are with their job and working environment. Employee satisfaction is the terminology used to describe whether employees are happy, contended and fulfilling their desires and needs at work. Employee satisfaction leads to a positive ambience at the workplace. It measures whether an employee's needs are being met at work and how satisfied they are with their overall work experience. The focal point in Employee Satisfaction is on the employee's individual feelings, positive or negative, about their employment relationship. It is subjective in nature and is internally-focused on an employee's emotional state of happiness. Rousseau (1978) identified three components of employee satisfaction: they are characteristics of the organization, job task factors, and personal characteristics.

\section{Importance:}

Derek R. Allen \& Merris Wilburn, (2002). The success of any company is directly related to the satisfaction of the employees who embody that company, that retaining talented people is critical to the success of any organization, Freeman, (2005) .Studies shows that businesses that excel in employee satisfaction issues reduce turnover by $50 \%$ from the norms, increase customer satisfaction to an average of $95 \%$ \& lower labor cost by $12 \%$., Carpitella, (2003). The more satisfied an employee is, the less turnover and absenteeism occurs, Maloney, \& McFillen, (1986). Judge, et. al, (1993), on the other hand, mentions that employee satisfaction is positively correlated with motivation, job involvement, organizational citizenship behavior, organizational commitment, life satisfaction, mental health, and job performance, and negatively related to absenteeism, turnover, and perceived stress and identify it as the degree to which a person feels satisfied by his/her job.

\section{Concept of quality of work life}

Quality of Work Life refers to the level of satisfaction, motivation, involvement and commitment individuals experience with respect to their lives at work. Companies interested in enhancing employees Quality of Work Life generally try to instill in employees the feelings of security, equity, pride, internal democracy, ownership, autonomy, responsibility and flexibility. They try to treat employees in a fair and supportive manner, open communication channels at all levels, offer employees opportunities to participate in decisions affecting them and empower them to carry on with their assignments. QWL is the employee satisfaction with a variety of needs through resources, activities and outcomes stemming from participation of needs (Sirgy et al. 2001). It basically refers to relationship between the employees and the ecosystem in which he works. It focuses on creating a working environment where employees work co - operatively and achieve results collectively.

\section{Importance}

Quality of Work Life program has become important in work place due to Increase demands at work, Loss of long term employee guarantees, need for enhanced work place skills, Greater competition for talent, Increased women in work force. Good quality of Work Life leads to an atmosphere of good impersonal relations and highly motivated employees who strive for their development. Organizations are seeking the ways for increasing the QWL in order to retain the best employees and attract the most talented employees. Louis and Smith (1990) research identified the importance of QWL in reducing employee' turnover and employee well-being impacting on the services offered.

\section{Review of Literature}

\section{Employee satisfaction}

Employees will have a positive attitude toward their job if they have high satisfaction, in the opposite view, employees with low satisfaction will have a negative attitude towards their job (Robbins, 1993). The fact that some researchers showed that if satisfaction is absent in job, it means that there is always opportunity or prediction that employee will leave the job (Alexander, Liechtenstein \& Hellmann, 1998; Jamal, 1997). Likewise, Smith (1992) claimed that job satisfaction can lead to reduce the cost for the organizations by decreasing job mistakes, mission faults, and absences from work. As regards Ramayah, Jatan and Tadisina (2001), job satisfaction interprets how willing enforce people to go to work, what makes people happy to go to work, and do not to leave the job. Employee satisfaction is very important factor which helps the organization know about general emotions and expectations about the workplace, job and environment of employees.

Cranny, Smith \& stone (1992) defined Employee Satisfaction as the combination of affective reactions 
to the differential perceptions of what he/she wants to receive compared with he/she actually receives. According to Moyes, Shao \& Newsome (2008) the employee satisfaction may be described as how pleased an employee is with his or her position of employment. As Spector (1997) defined job satisfaction as all the feelings that a given individual has about his/her job and its various aspects. Employee satisfaction is a comprehensive term that comprises job satisfaction of employees and their satisfaction overall with companies ${ }^{\text {ee }}$ policies, company environment etc.

Survey results of Kathawala, Moore and Elmuti (1990) tell that the salary package is the only factor that enhances the motivational and satisfaction level of salaried employees in an automobile sector. It is important to note that reward or compensation) is a very important tool to control employee turnover. It also encourages the organizational commitment of the employee, which in turn attract besides the employee with the job (Zobal, 1998; Chiu et al., 2002; Moncarz et al., 2009).

Job satisfaction is emphasized to be the most major element in the organization. Because of to achieve success, the organization must keep their employees satisfied in the job. Similarly, job satisfaction is explained as the level of the positive or negative feeling of staffs toward their job. It is a sentimental response to job obligation as well as to the social conditions of the work place (Ramman, 2011).

Employees ${ }^{\text {ee }}$ job satisfaction sentiments are important because they can determine collaborative effort. Consistent with this reasoning, Likert (1961) has argued that collaborative effort directed towards the organization "e goals is necessary for achievement of organizational objectives, with unhappy employees failing to participate (effectively) in such efforts.

\section{Quality of work life}

Ganguli and Joseph (1976)1 studied Quality of Work life among young workers in Air India with special reference to life and job satisfaction issues. Findings indicate that, of the various physical and psychological working conditions, pride in organization, job and community respect, reasonable working hours, etc. are some variables positively correlated with QWL than friendship with colleagues, good work location and physical strain, varsity of skills and risks of injury.
Chan and Einstein (1990) in their study explored that QWL reflects as a concern for people's experience at work, their relationship with other people, their work settings and their effectiveness on the job.

Feldman (1993) defined Quality Work Life is the quality of relationship between employees and the total working environment. Lau et al,(2001) described QWL as the favourable working environment that supports and promotes satisfaction by providing employees with rewards, job security, and career growth opportunities.

Hoque and Rahman (1999) found that Quality of work life is important for job performance, job satisfaction, labor turnover, labour management relations which play a crucial role in determining the overall well being of any industrial organization. They found in their study that workers of the private sector textile mills perceived significantly high Quality of work life than the workers of the public sector textile mills.

\section{Factors of employee satisfaction}

Through review of literature different factors or variables affecting the satisfaction of employees can be identified as Organization Development, Policies of Compensation and Benefit, Job Satisfaction, Promotion and Career Development, Job Security, Relationship with Superiors, overall Working Environment \& Condition, Leadership Styles, Work Group, personal factors like personality, education, expectation, age, gender differences etc.

\section{Factors and dimensions of Quality of Work Life.}

Quality of work life is crucial for organizations to persistently attract and retain employees which was found by (Akder 2006) in their study and also it has become significant in the last two decagon due to the increasing demands of today's business environment and family structure. Lau (2000) defined QWL as the favourable conditions and environments of a workplace that support and sustain employees' satisfaction by providing them with job security and reward. QWL encompasses various facets such as working conditions, working time, mode of wages payment, health hazards, and management behaviour throughout the process of responding to the needs of the employees Therefore, QWL involves some financial and non-financial benefits, as well as management behaviour towards workers. 
In the year 1974, Richard Walton, an American Professor, had identified and introduced the following factors and dimensions -1) Adequate and fair compensation: The sum of money employees receives for their mental or physical work or both, according to social criteria, volume of work and similar jobs. 2) Safe and healthy working condition: A safe physical working condition and reasonable working hours. 3) Opportunity for condition growth and security: Improved conditions to provide opportunities for individual development and opportunities for utilizing acquired skills and providing job security and income. 4) The social relevance of work life: Staffs perception of social responsibility. Social responsibility of an organization refers to the organization's commitment to ethical behaviour as a social institution in its broad sense .5) Total life space: Balance between employees work life and life responsibilities. 6) Social integration in the work organization: Integration and social cohesion refers to creating working environment in a way that the staffs have a sense of belonging (Hamidi \& Mohamadi, 2012). 7) Constitutionalism: Freedom of expression (the right to dissent or criticism of the attitude of supervisors), ability to respond to organizational issues, including salary, bonuses and job security and the organization's desire to regulate them are among the elements of quality of work in the organization. 8) Development of human capabilities: Using autonomy and self-control, benefitting from diverse skills, accessing to information about the future, and planning and executing activities for the employees are among the mentionable items in quality of work life (Kamali Sajjad \& Abbasi, 2014).

\section{Indian scenario}

The quality of work Life (QWL) Apart from ensuring fair pay, the fair treatment of employees and safe working conditions, many companies respond to specific employee needs. In India, some of the companies that emphasize the quality of work life are Hewlett-Packard, Smith Kline Beecham, American Express, Colgate Palmolive, Gillette, Dr.Reddy's Laboratories, Reliance and Maruti Udyog Limited.HP allows flexible working arrangements for its employees and follows certain innovative practices such as allowing employees to avail leave for special occasions (marriage, exam preparation, adoption of a child, bereavement in the family, and paternity). QWL in India has emerged as a movement due to the Changing profile of the Indian employee and worker from illiterate, rural, low caste individual to educated, urban and essentially belonging to upper strata of caste structure has made him/her more concern for own hopes and aspirations.

\section{Conclusion}

Quality of work life represents concern for human dimensions of work and relates to employee job satisfaction and organisational development. Improved Quality of Work Life leads to improved performance. Performance means not only physical output but also the behviour of the worker in helping his colleagues in solving job related problems, team spirit and accepting temporary unfavourable work conditions without complaints. There is positive and significant relationship between QWL and employees' job satisfaction. The employer has a responsibility to ensure the satisfaction of all of its employees. There are many precautions that managers can take to make certain that they are meeting the working needs of their employees. Recognition of an employee's hard work is essential to his or her satisfaction in the workplace. Providing employees with the opportunity for growth is also a major contributor to satisfaction. Because performing the same job becomes uninteresting, it is important to challenge employees with work that they can accomplish but stretches their abilities. Management should have a positive effect on, and seek to support the happiness of, the firm's employees. Reasons for this are not solely to benefit the employees as companies also stand to gain from employee satisfaction. it is very true to say that high degree of QWL leads to job satisfaction which ultimately results in effective and efficient performance. It is necessary to ensure quality work life for all-round peace and prosperity. Better quality of work life leads to increased employee morale. It minimizes attrition and checks labor turnover and absenteeism Satisfied employees will work harder for the company and plan to stay at the company, ultimately reducing that company's labor costs.

\section{References:}

[1] Walton, R.E., (1975). Criteria for Quality of Working Life. In Davis, L.E., Cherns, A.B. and Associates (Eds.) The Quality of Working Life, The Free Press, New York, NY, 1: 91- 104.

[2] Ganguli, O.N. and Joseph, J.S. (1976). "Quality of working life: work prospects and aspirations of young workers in Air India, Bombay”. Central Labour Institute. 
[3] Hoque, M.E. and Rahman, A. (1999). "Quality of working life and Job Behavior of workers in Bangladesh: A comparative study of private and public sectors", Indian Journal of Industrial Relations, Vol.35, no.2, pg $175-184$.

[4] Robbins, S. P. (1993). Organizational behavior. Englewood Cliffs, N.J: Prentice-Hall.

[5] Ramman, M. (2011). Factors affecting job satisfaction of the employees in travel and tourism companies in Amman. International Bulletin of Business Administration, pp- 348-355.

[6] Higgins, C., Duxbury, L. and Living, R.H. (1992). "Work family conflict in the dual career family Organizational Behaviour and Human Decision Processes", 51: pg 51-75.
[7] Greenhaus, J., \& Powell, G. (2006). When work and family are allies: A theory of work-family enrichment. Academy of Management Review, 31(1), 72-92.

[8] Yazdani, B. O., Yaghoubi, N. M., \& Giri, E. S., (2011). Factors affecting the Empowerment of Employees. European Journal of Social Sciences, 20 (2), pg- 267-274.

[9] Ahmad, S. (2015). Human Resource Management: In practice: First Edition; New Delhi: Tilak Wasan Discovery Publishing House PVT Ltd.

[10] Mohammad Baitul Islam (2012), "Factors Affecting Quality of Work Life: An Analysis on Employees of Private Limited Companies in Bangladesh", Global Journal of Management and Business Research, Vol. 12, pg 18 